\title{
Pengaruh Media Pembelajaran Crosword Puzzle Dengan Model Discovery Learning Terhadap Hasil Belajar Siswa Pada Konsep Gelombang Bunyi Di SMAN 1 Boliyohuto
}

\author{
Iswanto A. Yunus, Raghel Yunginger, Mursalin, Dewi Diana Paramata, Dewa Gede Eka \\ Setiawan, Abdul Haris Odja* \\ Program Studi Pendidikan Fisika, Universitas Negeri Gorontalo \\ *Email: abdulharis@ung.ac.id
}

Received: 25 November 2021; Accepted: 23 Desember 2021; Published: 24 Desember 2021 DOI: http://dx.doi.org/10.29303/jpft.v7i2.3263

\begin{abstract}
This study aims to determine the effect of crossword puzzle learning media with discovery learning models on student learning outcomes on the concept of sound waves. This research is a quasiexperimental type of research using one class (one samples) only the experimental class using the One Group pretest posttest design. In this study, learning was conducted three times online with the discovery learning model. The instrument used in data collection is an essay test of learning outcomes. The method used to analyze the data is descriptive analysis technique, namely normality test, hypothesis testing with a significance level of 5\%. Based on hypothesis testing using parametric statistics t test obtained $t_{\text {Calculate }}$ $\left(5.789>t_{\text {tabel }}(2.024)\right.$ with a significant level $=0.05$. where hypothesis one $\left(H_{-} 1\right)$ is accepted. This shows that there are differences in student learning outcomes before and after learning using learning media crossword puzzle with the discovery learning model. This result is also shown from the increase in student learning outcomes on the posttest test which is higher than in the pretest test with an average value of $76.03 \%$ and $65.71 \%$. Thus the use of crossword puzzle media with the discovery learning model affects the results student learning.
\end{abstract}

Keywords: Crossword Puzzle ; Discovery Learning ; Learning Outcomes

\section{PENDAHULUAN}

Fisika adalah salah satu ilmu dalam bidang sains yang sangat rumit untuk diselesaikan tanpa memahami konsepkonsep didalamnya. Sebagian besar konsepkonsep fisika masih merupakan sesuatu yang abstrak bagi siswa. Hal ini dapat terlihat pada saat siswa kurang menggali pengetahuan tentang konsep-konsep dasar dari materi tersebut. Akibatnya siswa belum mampu membangun pemahaman yang fundamental pada awal mempelajari fisika. Hal ini tentunya akan berpengaruh terhadap hasil belajar siswa.

Sebagai seorang tenaga pendididik guru memiliki peran yang sangat penting guna meningkatkan kualitas hasil belajar siswa di dalam kelas. Guru professional sanggup memilih model dan media pembelajaran yang tepat untuk digunakan nanti dalam proses pembelajaran
Penggunaan model dan media pembelajaran ini sangat bermanfaaat dalam proses pembelajaran bila digunakan secara tepat.(Angraini et al., 2019).

Berdasarkan hasil wawancara yang telah dilakukan dengan guru mata pelajaran fisika kelas XI SMA Negeri 1 Boliyohuto yang menyatakan bahwa dalam proses pembelajaran siswa sering merasa jenuh dikarenakan pembelajarannya kurang menarik serta siswa sedikit merespon guru ketika pembelajaran berlangsung. Hal ini dapat terlihat dari kegiatan siswa pada saat proses pembelajaran, siswa tidak memperhatikan penjelasan guru, mengantuk serta bermain dalam kelas. Tentunya hal ini akan mempengaruhi hasil belajar siswa itu sendiri. Sementara itu, dalam proses pembelajaran guru jarang menggunakan media pembelajaran, adapun ketika menggunakan media pembelajaran sebatas 
gambar sederhana saja dan tidak melibatkan semua siswa untuk turut berberan aktif.

Salah satu solusi dari permasalahan di atas adalah menerapkan model discovery learning. Penggunaan model discovery learning untuk merubah kondisi belajar yang pasif menjadi aktif dan kreatif. Siswa berperan aktif dalam proses pembelajaran dengan menjawab berbagai pertanyaan atau persoalan dan memecahkan persoalan untuk menemukan suatu konsep. Model pembelajaran penemuan dapat mendorong siswa mengajukan dugaan awal penggunakan bahan dan permainan yang bervariasi, memberikan kesempatan pada siswa untuk memuaskan keingintahuan mereka.(Persada, A., 2016). Sementara itu solusi dalam media pembelajaran yaitu membuat sebuah aplikasi pembelajaran yaitu aplikasi pembelajaran crossword puzzle yang memudahkan siswa untuk memahami materi pembelajaran sebagai mana yang dijelaskan (Weisskirch, 2006) bahwa teka-teki silang adalah cara untuk mereview meninjau ulang meteri pembelajaran setelah dijelaskan.

Pada penelitian ini model discovery leraning disertai dengan media aplikasi pembelajaran crossword puzzle. Hal ini bertujuan untuk materi yang telah dipelajari mampu diingat dan hasil belajar fisika siswa dapat meningkat, karena guru menggunakan aplikasi crossword puzzle sebagai materi dan evaluasi siswa. Sebagai mana yang telah dikemukakan oleh (Weisskirch, 2006) bahwa teka-teki silang adalah cara untuk mereview meninjau ualng meteri pembelajaran setelah dijelaskan. Materi pembelajaran yang digunakan didalam pembuatan teka-teki silang adalah materi yang akan dipelajari. Hasil penelitian beberapa peneliti (Şengören dkk, 2009; Sutopo, 2016; Fazio dkk, 2008 dalam (Nurul dkk ,2016) menunjukan siswa mengalami kesulitan pada materi gelombang. Kesulitan yang dialami siswa lebih banyak terletak pada pemahaman konsep

Kehadiran teknologi terkhusus android saat ini sudah sangat berkembang pesat tidak hanya orang dewasa dan remaja akan tetapi juga anak-anak sudah dapat menggunakannya. Siswa telah tumbuh dengan menggunakan perangkat seperti computer, android (Ponsel) dan konsol video untuk hampir setiap kegiatan dari kegiatan belajar, bekerja, atau hanya sebatas hiburan". Pemanfaatan android sebagai media pembelajaran memberikan kesempatan belajar yang lebih mendalam (Rogozin, 2012), sehingganya diperlukan inovasi baru dunia pendidikan dengan membuat sedemikian rupa android menjadi media pembelajaran siswa.

Penggunaan media teka-teki silang telah dilakukan oleh (Zulfajri, M \& Amelia, 2016), melalui discovery learning ada pada mata pelajaran kimia, hasilnya menunjukkan bahwa model discovery learning dengan media teka-teki silang sangat disukai oleh siswa dan layak digunakan dalam proses pembelajaran sehingga mampu meningkatkan hasil belajar siswa. Berdasarkan pemaparan yang telah dijelaskan, maka peneliti melakukan penelitian dengan judul "Pengaruh media pembelajaran crosword puzzle dengan model discovery learning terhadap hasil belajar siswa pada konsep gelombang bunyi di SMAN 1 Boliyohuto".

\section{METODE PENELITIAN}

Penelitian ini merupakan jenis penelitian quasi eksperimen dengan menggunakan One Group Pretest-posttest design.Subjek dalam penelitian ini adalah siswa XI MIA 4 dengan jumlah siswa 20 orang. Penelitian ini berlangsung di SMA Negeri 1 Boliyohuto pada bulan April tahun ajaran 2021. Siswa diberikan pretest dan postest berupa essay sebanyak 11 nomor 
Penelitian ini dilakukan tiga kali pertemuan secara daring menggunakan media crossword puzzle dengan model pembelajaran discovery learning.

Media pembelajaran crossword puzzle adalah aplikasi pembelajaran yang dirancang khusus untuk digunakan sebagai strategi pembelajaran yang mana dapat membantu siswa dalam meninjau ulang materi pembelajaran yang telah dipejari.

Data hasil belajar dalam penelitian ini diperoleh melalui tes hasil belajar berupa essay berjumlah 11 (sebelas) butir soal dengan jumlah responden sebanyak 20 orang siswa, diberikan kepada siswa sebelum dan setelah penggunaan media crossword puzzle. Analisis data dalam penelitian ini menggunakan Analisis secara deskriptif yaitu uji normalitas, uji hipotesis.. Uji statistik dilakukan pada taraf signifikansi $5 \%$.

Pengujian untuk normalitas data adalah sebuah uji yang dilakukan dengan tujuan untuk menilai sebaran data pada sebuah kelompok data atau variabel, apakah sebaran data tersebut berdistribusi normal atau tidak. Dasar pengambilan keputusan adalah Jika nilai 1 hitung $>1$ tabel maka Ho ditolak, dan jika nilai 1 hitung $<1$ tabel, maka Ho terima. Hipoteisis statistika yang digunakan yaitu :

$\mathrm{H}_{0}$ : Data terdistribusi normal

$\mathrm{H}_{1}$ : Data tidak terdistribusi normal

(Murwani, 2001)

Adapun Teknik uji yang digunakan dengan menggunakan statistik uji Kolmogorov Smirnov dengan persamaan yaitu :

$D=\left[\mathrm{F}_{\mathrm{s}}(\mathrm{x})-\mathrm{F}_{\mathrm{t}}(\mathrm{x})\right] \quad \operatorname{Max}$

Keterangan :

$\mathrm{D}=$ Nilai hitung

$\mathrm{Fs}(\mathrm{x})=$ Distribusi frekuensi kumulatif sampel

$\mathrm{Ft}(\mathrm{x})=$ Distribusi frekuensi kumulatif teoritis

Pengujian hipotesis dilakukan untuk mengetahui apakah terdapat perbedaan antara hasil belajar siswa pada konsep gelombang bunyi sebelum dan setelah penggunaan media pembelajaran crosword puzzle dengan model discovery learning. Pengujian hipotesis dalam penelitian ini menggunakan uji statistik parametric dengan statistik uji t-test. Adapun rumus yang digunakan yaitu :

$$
\mathrm{t}=\frac{\bar{x}-\mu_{0}}{\frac{s}{\sqrt{n}}}
$$

Keterangan :

$\mathrm{t}=$ Harga $\mathrm{t}$ yang dihitung

$\bar{x}=$ Nilai rata-rata $\mathrm{xi}$

$\mu_{0}=$ Nilai yang dihipotesiskan

$\mathrm{s}=$ Simpangan baku

$n=$ Banyaknya subjek penelitian

(Sudjana, 2005)

Pengujian hipotesis statistik dalam penelitian ini adalah sebagai berikut:

Ho: $\boldsymbol{\mu 1}=\boldsymbol{\mu} \mathbf{2}$ (Tidak terdapat perbedaan antara hasil belajar siswa pada konsep gelombang bunyi sebelum dan setelah penggunaan Media Pembelajaran Crosword Puzzle Dengan Model Discovery Learning di SMAN 1 Boliyohuto)

H1: $\boldsymbol{\mu} \mathbf{1} \neq \boldsymbol{\mu} \mathbf{2}$ (Terdapat perbedaan antara hasil belajar siswa pada konsep gelombang bunyi sebelum dan setelah penggunaan Media Pembelajaran Crosword Puzzle Dengan Model Discovery Learning di SMAN 1 Boliyohuto"

Taraf signifikansi $\alpha=0,05$, maka kriteria pengambilan keputusan:

Jika $t_{\text {hitung }}>t_{\text {tabel }}$ maka $H_{0}$ ditolak

Jika $t_{\text {hitung }}<t_{\text {tabel }}$ maka $H_{0}$ diterima

Data yang dianalisis harus memperhatikan kriteria ketuntasan belajar siswa pada table 1 berikut. 
Tabel 1. Kriteria Ketuntasan Minimum

\begin{tabular}{ll}
\hline $\begin{array}{l}\text { Kriteria } \\
\text { Ketuntasan }\end{array}$ & Keterangan \\
\hline Nilai $\geq 75$ & Tuntas \\
Nilai $<75$ & Tidak Tuntas \\
\hline
\end{tabular}

(Sumber:KKM SMAN 1 Boliyohuto)

\section{HASIL DAN PEMBAHASAN \\ Hasil}

Analisis hasil belajar siswa pada pretest dan postest di tiap level kognitif digambarkan sebagai berikut.

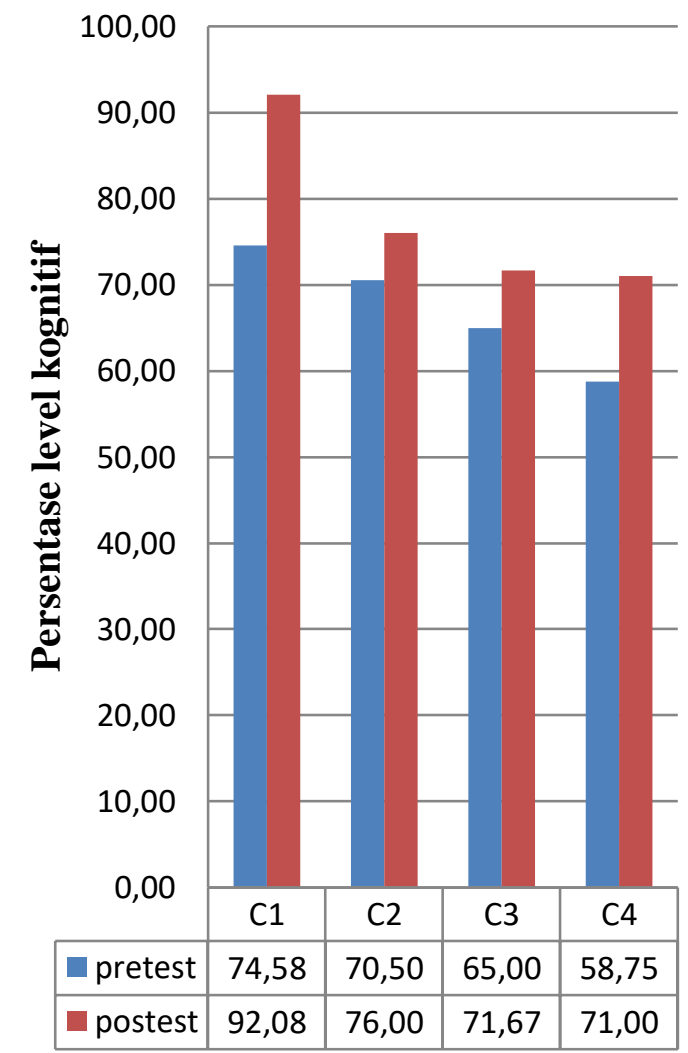

Gambar 1. Diagram analisi level kogntif

Berdasarkan gambar 4.1 terlihat kriteria kognitif $\mathrm{C} 1$ sampai $\mathrm{C} 4$ yang diperoleh dari persentase pretest maupun postest menunjukan $\mathrm{C} 1$ memeliki persentase lebih tinggi dibandingkan C2, C3 sampai dengan $\mathrm{C} 4$.

Hasil pengujian normalitas data menunjukan data terdistribusi normal dengan 1 hitung $<1$ tabel. Hasil tersebut dapat dilihat pada Tabel 2.
Tabel 2. Hasil Uji Normalitas data

\begin{tabular}{llll} 
& \multicolumn{3}{c}{ Uji Kolmogorov-Smirnov } \\
Tes & 1 hitung & 1 tabel & Status \\
\hline Pretest & 0.175 & 0.294 & Berdistribusi Normal \\
Posttes & 0.153 & 0.294 & Berdistribusi Normal \\
\hline
\end{tabular}

Tabel 3 Menunjukan 1 hitung $<1$ tabel untuk taraf nyata $\alpha=0.05$. Maka Hipotesis $\left(\mathrm{H}_{0}\right)$ diterima dan Hipotesis $\left(\mathrm{H}_{1}\right)$ ditolak. Bisa disimpulkan bahwa data terdistribusi normal

Pada pengujian hipotesis maka diperoleh $t_{\text {Hitung }}>t_{\text {tabel }}$ dengan taraf nyata $\alpha=0.05$. hasil pengujian hipotesis yang telah dilakukan yang mana menyimpulkan terdapat perbedaan antara hasil belajar peserta didik pada pretest dan postest sebelum dan setelah diberikan perlakuan.Hasil pengujian hipotesis sebagaimana disajikan pada tabel 3.

Tabel 3. Hasil Pengujian Hipotesis

\begin{tabular}{cccc}
\hline Kelas & $t_{\text {Hitung }}$ & $t_{\text {Tabel }}$ & Status \\
\hline Prettes & 5.789 & 2.093 & $H_{0}$ di tolak
\end{tabular}

\section{Pembahasan}

Data hasil belajar dalam penelitian ini diperoleh melalui tes hasil belajar berupa essay. Item soal sejumlah 11 nomor ranah kognitif $\mathrm{C} 1, \mathrm{C} 2, \mathrm{C} 3$ dan $\mathrm{C} 4$. Tes essay diberikan kepada siswa sebelum (pre-test) dan setelah (post-test) penggunaan media crosword puzzle berbasis discovery learning dilakukan.

Berdasarkan grafik 4.1 tentang hasil belajar kriteria kognitif $\mathrm{C} 1$ sampai $\mathrm{C} 4$ yang diperoleh dari persentase pretest maupun postest menunjukan $\mathrm{C} 1$ memeliki persentase lebih tinggi dibandingkan C2, C3 sampai dengan C4. Hal ini menunjukan bahwa pembelajaran dengan menggunakan media crossword puzzle mampu meningkatkan 
kemampuan siswa pada kriteria $\mathrm{C}$, sedangkan pada kriteria C4 siswa belum maksimal meningkatkan kemampuan kognitif yang dimiliki. Dengan demikian Kemampuan yang dimiliki siswa pada kriteria $\mathrm{C} 4$ belum bisa melampaui kemampuan siswa pada kriteria $\mathrm{C} 1$ baik pretest maupun postest, Hasil ini sesuai dengan penelitian yang dikemukakan oleh (Radili, 2012) yang menunjukan bahwa penggunaan media crossword puzzle dapat meningkatkan kemampuan $\mathrm{C} 1$ mengingat pelajaran yang telah disampaikan selama pembelajaran dan bagaimana siswa tersebut bisa menerapkannya serta mampu memecahkan masalah yang timbul sesuai dengan apa yang telah dipelajari.

Pada pengujian hipotesis memberikan kesimpulan bahwa terdapat perbedaan hasil belajar siswa pada konsep gelombang bunyi sebelum dan setelah penggunaan media pembelajaran crosword puzzle dengan model discovery learning. Hal ini dikarenakan pengaruh penggunaan media crosword puzzle, siswa diberikan kesempatan untuk mempelajari ulang materi yang terdapat pada media crossword puzzle dan mengevaluasi materi tersebut dalam bentuk permainan Seperti yang dijelaskan (Weisskirch, 2006) bahwa teka-teki silang adalah cara untuk mereview meninjau ulang meteri pembelajaran setelah dijelaskan.

Perbedaan hasil tersebut dapat dilihat pada perolehan skor tiap kriteria kogntif, Pada saat postest yang cenderung tinggi terjadi pada C1 (Pengetahuan) terdapat pada item soal no. 4,8,9,10. Dari ke 4 soal tersebut siswa lebih dominan menjawab soal nomor 4, hal ini didukung oleh jawaban siswa pada pertanyaan yang telah diberikan terkait topik gejala-gejala gelombang bunyi, dimana siswa diminta untuk menyebutkan beberapa sifat umum gelombang bunyi ! Siswa menjawab : pembiasan (refraksi), pemantulan (refleksi), pelenturan (difraksi), interferensi, dan polarisasi. Setelah hasil perhitungan diperoleh, ternyata data menunjukan adanya perbedaan antara pretest dan postest. Perbedaan itu ditunjukan dengan presentase postest lebih tinggi yaitu $92.08 \%$ dibandingkan dengan pretest $74.58 \%$.

Sedangkan pada saat postest yang cenderung lebih rendah terdapat pada $\mathrm{C} 4$ (menganalisis) dengan item soal no.2 dan 6 . Dari ke 2 soal tersebut siswa lebih dominan menjawab soal nomor 6 , hal ini didukung oleh jawaban siswa pada pertanyaan yang telah diberikan terkait topik perambatan gelombang bunyi pada berbagai medium, dimana siswa diminta untuk menganalisis gelombang bunyi akan bertumbukan jika bertemu dengan gelembang bunyi lainnya. Benar atau Salah? berikan alasan! Siswa menjawab : Salah, ketika dua gelombang bertemu, maka akan menghasilkan superposisi. Setelah itu, keadaan mereka ( arah dan Kecepatan) kembali seperti semula. Ketika dua partikel bertemu, keduanya akan bertumbukan, sesudah itu, keadaan (arah dan kecepatan) mereka dapat berbeda dengan keadaanya sebelumnya

Setelah hasil analisis diperoleh, ternyata data menunjukan adanya perbedaan antara pretest dan postest. Perbedaan itu ditunjukan dengan presentase postest lebih tinggi yaitu $71.00 \%$ dibandingkan dengan pretest $58.75 \%$. Analisis data ini menerangkan bahwa terdapat peningkatan selisih yang berbeda setelah diterapkanya media pembelajaran crossword puzzle Sebagaimana penelitian yang telah dilakukan oleh (Muflikah, N. K., \& Sucahyo, 2019) yaitu selisih berbeda dari hasil belajar tidak terlalu besar, artinya terdapat konsistensi dari perlakuan yang diberikan oleh peneliti.

Jika dilihat dari isi media crossword puzzle, menu yang terdapat di media crossword puzzle sangat membantu siswa 
dalam menguasai materi pembelajaran. Mulai dari menu bahan ajar menyajikan materi pembelajaran dalam bentuk elektronik sehingganya siswa tidak kesulitan lagi mencari materi yang akan dipelajari nanti. Kemudian setelah mempejari materi tersebut dapat mengevaluasi kembali materi yang dipelajari dengan dibantu menu TTS yang sudah tersedia di media crossword puzzle. Sebagaimana yang dikemukakan oleh (Sari, N., 2017) yaitu siswa antusias mengikuti pembelajaran dengan adanya pengisian teka-teki silang sebagai evaluasi di akhir pembebelajaran sebagai pengulangan materi. Dengan mengisi TTS tersebut siswa dapat mengetahui sejauh mana penguasaan materi yang baru selesai di pelajari.

Penggunaan media pembelajaran crosword puzzle dengan model discovery learning memiliki pengaruh terhadap hasil belajar siswa, sebagai mana hasil penelitian yang telah dilakukan oleh (Handayani, 2016) yang menerangkan bahwa penggunaan media crossword puzzle memiliki pengaruh yang signifikan terhadap hasil belajar siswa. Di sisi lain (Angraini et al., 2019) mengatakan dalam penelitiannya bahwa penggunaan media teka-teki silang dapat meningkatkan motivasi belajar yang mempengaruhi hasil belajar siswa. Dengan menggunakan media crossword puzzle dapat memotivasi siswa untuk melakukan sendiri penemuan sebuah konsep dari topik yang dipelajari, sehingga pembelajaran yang dilakukan lebih membuat siswa mengerti dengan materi yang dipelajari.

Hasil penelitian ini sesuai dengan penelitian yang telah dilakukan (Jaafar, 2020) pembelajaran discovery learning berbantuan media crossword puzzle berbasis android berpengaruh positif terhadap pemahaman konsep fisika peserta didik. Serta penelitian yang dilakukan (Angraini et al., 2019) yang menyimpulkan bahwa terdapat pengaruh penerapan model discovery learning disertai strategi pembelajaran aktif tipe teka-teki silang terhadap hasil belajar siswa.

Jadi berdasarkan penelitian ini ternyata penggunaan media pembelajaran crosword puzzle dengan model discovery learning yang diterapkan di SMA 1 Boliyohuto pada materi gelombang bunyi terjadi perbedaan kognitif yang cenderung tinggi berada di kemampuan menjelaskan $\mathrm{C} 1$ sedangkan $\mathrm{C} 4$ lebih rendah dari pada $\mathrm{C} 1$. Sehingganya peneliti merekomendasikan media crossword puzzle mungkin perlu dikembangkan lagi diantaranya mulai dari penambahan fitur Media PPT serta animasi video pembelajaran.

Adapun beberapa kendala selama proses Pembelajaran yaitu siswa sedikit kesulitan dan ragu dalam proses pemasangan aplikasi media crossword puzzle, hal ini dikarenakan aplikasi yang digunakan merupakan aplikasi baru sehingga sistem ponsel mendeteksi aplikasi berbahaya atau dicekal dari sumber tidak diketahui. Proses pembelajaran peneliti dan siswa terkendala jaringan saat sedang dalam proses pembelajarn berlangsung. Waktu yang digunakan menjadi bertambah lama tidak sesuai dengan jam pelajaran yang sudah terjadwalkan karena menunggu siswa agar bisa masuk ke pembelajaran dalam jaringan (Daring) google meet. Solusi yang diberikan peneliti dengan memberikan penjelaskan cara pemasangan aplikasi media crossword puzzle dan untuk mengtaktisi kendala molornya waktu peneliti menghubungi siswa secara pribadi melalui grub whatsapp dan memberikan kelonggaran waktu dalam mengirim tugas-tugas yang diberikan peneliti.

\section{Keunggulan media crossword puzzle}

Penggunaan media crossword puzzle memberikan kemudahan siswa dalam mengukuti proses pembelajaran apalagi 
belakangan ini proses belajar mengajar disekolah dilakukan secara daring. Media pembelajaran crosword puzze diformat dalam bentuk aplikasi, dimana menu-menu yang terdapat di media crossword puzzle sangat membantu siswa dalam menguasai materi pembelajaran. Mulai dari menu bahan ajar menyajikan materi pembelajaran dalam bentuk elektronik sehingganya siswa tidak kesulitan lagi mencari materi yang akan dipelajari nanti.

\section{Kekurangan media crossword puzzle}

Fitur yang terdapat pada media crossword puzzle masih kurang, sehingga perlu ditambahkan mulai dari Media PPT, Animasi dan video sehingga lebih memper mudah siswa dalam belajar.

\section{PENUTUP}

Berdasarkan hasil penelitian yang telah dilakukan dapat disimpulkan bahwa pembelajaran menggunakan media pembelajaran crossword puzzle dengan model discovery learning pada materi gelombang bunyi berpengaruh terhadap hasil belajar siswa. Hal ini ditunjukkan dengan hasil analisis dari hipotesis diperoleh $t_{\text {Hitung }}$ (5.789 $>t_{\text {tabel }}$ (2.024) dengan taraf nyata $\alpha=0.05$. Maka $H_{0}$ ditolak dan $H_{1}$ diterima. Berdasarkan uraian tersebut dapat dikatakan perlakuan yang diberikan dapat meningkatkan hasil belajar siswa dalam pembelajaran fisika.

Berdasarkan hasil penelitian yang dilakukan, maka peneliti memaparkan beberapa saran yang kiranya bisa dipertimbangkan untuk perbaikan kedepannya. Pelaksanaan pembelajaran daring lebih di atur dan menyesuaikan dengn kondisi peneliti dan siswa. Pembelajaran DARING mengharuskan pendidik untuk Memilih media yang tepat dan model pembelajaran yang tepat untuk memaksimalkan hasil pembelajaran.
Penggunaan Google Meet dalam proses pembelajaran Daring menjadi salah satu solusi bagi guru, untuk menjelaskan materi beserta contoh soal dan mendemontrasikan materi. Perlu dilakukan pengembangan media crossword puzzle pada penelitian berikutnya. Seperti penambahan fitur media PPT Animasi dan lain-lain sehingga lebih mempermudah siswa dalam belajar.

\section{REFERENSI}

Angraini, T. W. P., Rahmi, R., \& Delyana, H. (2019). Pengaruh Penerapan Model Discovery Learning Disertai Strategi Pembelajaran Aktif Tipe Teka-Teki Silang Terhadap Hasil Belajar Siswa Kelas Vii. Jurnal Edukasi Dan Sains Matematika (JES-MAT), 5(1), 54.

Handayani, F. (2016). Pengaruh Penggunaan Media Permainan Crossword Puzzle Terhadap Penguasaan Kosakata Bahasa Mandarin Pada Siswa Kelas X Akuntansi SMK Sejahtera Surabaya. Mandarin Unesa, 1, 1-9.

Jaafar, M. A. G. (2020). Pengaruh Model Pembelajran Discovery Learning Berbantuan Media Crossword Puzzle Berbasis Android Terhadap Pemahaman Konsep Getaran, Gelombang dan Bunyi.

Muflikah, N. K., \& Sucahyo, I. (2019). Efektifitas Penerapan Model Pembelajaran Inquiry Untuk Meningkatkan Hasil Belajar Siswa. 4(1). https://doi.org/https://doi.org/1307//00 3-2809.123.1.76

Murwani, S. (2001). Statistika Terapan (Teknik Analisis Data). Universitas Negeri Malang.

Nurul, D. (2016). Telaah Bahan Ajar Materi Gelombang dan Penyebab Kesulitankesulitan Siswa Memahaminya. Seminar Nasional Jurusan Fisika FMIPA UM 2016, 27-36.

Persada, A., R. (2016). Pengaruh Model Pembelajaran Penemuan (Discovery 
Learning) Terhadap Kemampuan Koneksi Matematika Siswa (Studi Eksperimen Terhadap Siswa Kelas VII SMPN 2 Sindangagung Kabupaten Kuningan Pada Pokok Bahasan Segiempat. Eduma, 5(2).

Radili, L. (2012). Pengaruh Penggunaan Crossword Puzzle Terhadap Hasil Belajar Siswa Pada Pembelajaran Teknologi Informasi Dan Komunikasi. 1(1), 1-12.

Rogozin. (2012). Physics Learning Instruments of XXI Century. Proceedings of The World Conference on Physics Education 2012.

Sari, N., P. (2017). Pengaruh penerapan Pembelajaran Kooperatif Disertai Teka-Teki Silang Terhadap Pemahaman Konsep Matematis Siswa Kelas XI IPS SMAN 4 Sijunjung Tahun pelajaran 2016/2017. In STKIP PGRI.

Sudjana, N. (2005). Penilaian Hasil Prose Belajar Mengajar. PT. Remaja Rosdakarya.

Weisskirch. (2006). Reviewing for Exams: Do Cross Word Puzzles Help in the Success of Student Learning? The Journal of Effective Teaching, 9(3), 410.

Zulfajri, M \& Amelia, R. (2016). Pengaruh model discovery learning dengan media teka-teki silang terhadap peningkatan hasil belajar siswa pada materi sistem koloid. Jurnal Edukasi Kimia, 1(1), 12-18. 